ENTREPRENEURSHIP AND SUSTAINABILITY ISSUES

ISSN 2345-0282 (online) http://jssidoi.org/jesi/

2020 Volume 7 Number 4 (June)

http://doi.org/10.9770/jesi.2020.7.4(46)
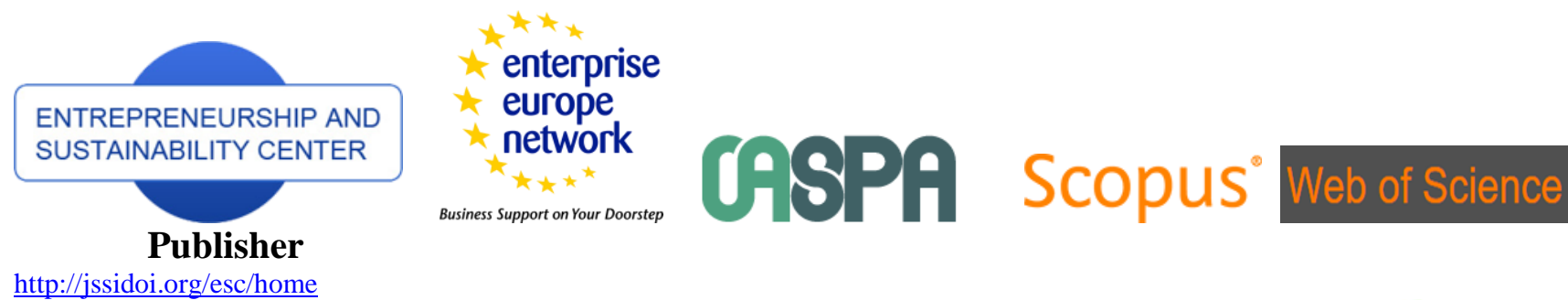

http://jssidoi.org/esc/home

Business Support on Your Doorstep

1) Clarivate

Analytics

\title{
BANK RISK MANAGEMENT IN THE CONDITIONS OF FINANCIAL SYSTEM INSTABILITY
}

\author{
Karlygash Kazbekova ${ }^{1}$, Ainagul Adambekova ${ }^{2}$, Sariya Baimukhanova ${ }^{3}$, Gulzhihan Kenges ${ }^{4}$, \\ Daurenbek Bokhaev ${ }^{5}$ \\ 1, 2, 5 Narxoz University, Almaty, Kazakhstan \\ ${ }^{3}$ Kazakh National University named by al-Farabi, Almaty, Kazakhstan \\ ${ }^{4}$ S.Seifullin Kazakh AgroTechnical University, Nur-Sultan, Kazakhstan

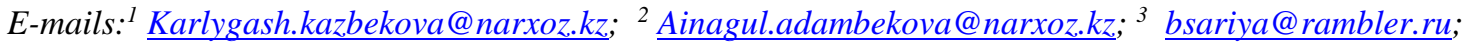 \\ ${ }^{4}$ gulji@mail.ru ; ${ }^{5}$ Daurenbek.bokhaev@narxoz.kz.
}

Received 16 December 2019; accepted 11 April 2020; published 30 June 2020

\begin{abstract}
Purpose of research is to influence prompt decision-making on the financial market in case of risk management of the bank. The banking sector is usually undergoing a serious reform phase. Investigating the bank's risk management basics using modern approaches to risk assessment and management in banking. The bank's risk leads to the loss of credit institutions and deterioration of liquidity, due to adverse events occurring, depending on internal and external factors. The article discusses the organization of the bank risk management system, methods of risk management, quantitative and qualitative risk assessment. Banks use various methods to reduce their risk. The main types of risks, risk management system, ways of managing bank risks and ways to reduce them were considered. Quality of the bank's management, especially the risk management process, are the key factors that ensure stability and security of banks and the banking system as a whole. Common methods of scientific research have been developed. It is necessary to pay special attention to the risks of banks on the financial market. The deterioration of the situation in the financial market was associated with problems accumulated over many years, and some problems were solved, which in turn led to risks. The structure of the bank's risk management mechanism is presented, the characteristics of its elements are identified and the key objectives of the management mechanism are identified. In the study, all banks in the financial market were analyzed using the models in Gretl, with the major risk factors being analyzed. The mechanism of risk protection of banks consists of current methods of risk management and methods of its reduction. The roles, responsibilities and powers of regulatory bodies in the creation of an effective system of legal norms regulating the peculiarities of the risks taken by the bank are risk management as an element of the internal control system of banks. In the conditions of instability of the modern economy, the banking market can not be risky. The risk is in any bank activity, but it can be at different levels. In addition, the current risk management is to monitor important indicators and timely adopt operative decisions on banking transactions.
\end{abstract}

Keywords: bank risks; credit organization; profitability; stability; equity; risk management; competition; instability; financial markets; active transactions; internal control; bank system; banking supervisor authorities; executive management

Reference to this paper should be made as follows: Kazbekova, K., Adambekova, A., Baimukhanova, S., Kenges, G., Bokhaev, D. 2020. Bank risk management in the conditions of financial system instability. Entrepreneurship and Sustainability Issues,. Entrepreneurship and Sustainability Issues, 7(4), 3269-3285. http://doi.org/10.9770/jesi.2020.7.4(46)

JEL Classifications: G20, G21 


\section{ENTREPRENEURSHIP AND SUSTAINABILITY ISSUES}

ISSN 2345-0282 (online) http://jssidoi.org/jesi/

2020 Volume 7 Number 4 (June)

http://doi.org/10.9770/jesi.2020.7.4(46)

\section{Introduction}

The significance of risks in the banking sector is determined not only by potential losses from the credit organization, but also by using its clients' money and assets in its activities as a whole as part of the banking system. Risk management policy in the banking sector is a document defining the overall strategy, directions and risk management strategies, as well as the development strategy of the risk management system. The head of the state has noted the need to complete the clearing of the bad loan portfolio (Nazarbayev, 2018). For 25 years, our Tenge has been established on the Kazakhstani market, but changes in the market are still affecting our Tenge, and the exchange rate is changing every day.

The Bank's failure in the market economy is a natural process that promotes the recovery of the banking sector. Given that the banks did not pay much attention to the risks, In July 2018 the legislative measures were taken to strengthen the National Bank's supervisory mandate to avoid a repeat of risk management policy. These amendments were enacted legally on $1^{\text {st }}$ of January 2019. The National Bank's management has introduced a riskoriented surveillance system based on the SREP (Supervisory Review and Evaluation Process).

This, of course, will have a positive impact on the banking sector and will improve its efficiency. In introducing the new system, the National Bank will ensure the continuous functioning of the financial sector and timely respond to the most pressing problems.

The new system will become more and more adaptable to the changing nature of emerging financial risks as the modern markets develop. The VIII Congress of Kazakhstani Financiers, jointly implemented by the National Bank and the Financiers' Association of Kazakhstan, is one of the most important measures. Decisions were made in the following matters such as the application of the national currency, introduction and use of risk-based approaches in financial supervision, the cash flow prospects, the protection of the rights of financial service consumers in the modern world.

In order to prevent the situation with high risk policy of Kazakhstan banks, starting from January 2019, risk-based supervision was introduced. The banks' capitalization requirements and the risk management system were tightened. The recovery of the banking sector and the introduction of new methods of regulation and supervision considerably reduce the risks for bank depositors. At the same time, due to the growth of bad debt balances and capitalization, banks tighten credit requirements.

\section{Research background}

Today we can be sure that the timely and implemented program not only gives impetus for new loans, but also improves the banks' loan portfolio, which, in turn, has a positive impact on the banking sector. The study of domestic and foreign scholars on the subject such as Lisak B.I. (2017), Iskakov U.M. (2016), Caplinska, A., Tvaronavičiene, M. (2020) is important for theoretical and analytical developments to analyze and evaluate credit risks in the bank's loan portfolio, which predetermines the bank risk vulnerability.

Banking operations are at greater risk due to market changes. Besides the functional function, the bank performs public functions and carries out monetary and credit policy. The bank's risk manifestations include reductions in profitability, loss of liquidity, loss of assets and so on. However, they generally affect the financial reliability of the credit institutions and the stability of the banking system as a whole, so they need to be managed and prevented (Lisak, 2017). In some banks, the share of unsecured collateral loans exceeds $80 \%$ of their loan portfolio. This is considered a very high risk. In this regard, last year the National Bank implemented the program of financial stability improvement of the second tier bank sector. A risk-based approach will be introduced since 2019 to prevent the situation with high risk policies of Kazakhstani banks. 


\section{ENTREPRENEURSHIP AND SUSTAINABILITY ISSUES}

ISSN 2345-0282 (online) http://jssidoi.org/jesi/

2020 Volume 7 Number 4 (June)

http://doi.org/10.9770/jesi.2020.7.4(46)

Its main purpose is to improve the banking sector through increased activity to reduce non-performing loans in the banking sector and to facilitate further growth of lending to the economy (Iskakov, 2016).

Five major banks (Eurasian Bank, JSC ATF Bank, Tsesnabank, Bank CenterCredit and Bank RBK) have been assisted within the framework of the state program. It was the main support for economic growth in the country. They represent $30 \%$ of the total loan portfolio of the whole banking system and $25 \%$ of all deposits and public sector deposits. Second-tier banks have eliminated an overwhelming majority of bad loans of the program participants and have started to lend to the economy.

In the framework of the program, banks have started lending to borrowers from the beginning of 2018, taking into account the problem loans of about 865.4 billion Tenge and 775.5 billion Tenge. In addition, special attention should be paid to doubling the non-performing loans by more than two times from $25 \%$ at the beginning of 2017 to $50 \%$ by November $1^{\text {st }}, 2018$. In its turn, banks' shareholders have invested 421 billion Tenge in five years. The bank must take measures to recapitalize the bank in the amount of more than 1.2 trillion Tenge, and quality of assets (rehabilitation of borrowers, additional collateral, loan collection).

Within the framework of strengthening the National Bank's supervisory mandate, legislative strengthening of the regulatory and supervisory mandate and made a decision to supervise the banks' real financial condition, and the banks adopted risk-based supervision principles, taking measures to prevent the asset and passive operations of banks to the threshold level.

These measures will eliminate the negative experience of banks in conducting banking operations, which will allow to stabilize the banking sector and increase the role of banks in the medium-term perspective. In the first 9 months of 2018 inflation amounted to $3.3 \%$.

Annual inflation in September 2018 decreased to $6.1 \%$ compared to $7.1 \%$ at the end of the last year. On October 15 , the base rate increased from $9 \%$ to $9.25 \%$ to reduce the risk of inflation growth. A new level of basic rate increases demand for Tenge assets and saves favorable cash conditions.

Conditions for problem loans market at the legislative level were created to increase the effectiveness of problem assets solvency, tax incentives for transferring non-performing assets to special subsidiaries.

Last year, the program of financial sustainability of the banking sector adopted in January-September of the last year amounted to about 794.3 billion Tenge. Banks were obliged to reduce the "bad" assets in the amount of about 1.2 billion Tenge. Banks' bankruptcy or default is associated with economic conditions, independent ratings or political circumstances.

For example, in 2017 eight banks in the US were recognized bankrupt. In Russia in 2017-2018 there were insurance payments to 82 banks, and over the past three years there were 310 banks. In 2017, four banks were exposed to default, three of them - Bank Astana and Qazaq Banki JSC, Eximbank JSC, and Kazkommertsbank JSC owned by Halyk Bank.

It has made a significant contribution to the market of banks, especially the JSC Kazkommertsbank. If we take into account the share of the financial market, Qazaq Bank's share makes 0.9\%, Eximbank - 0.3\%, and Bank of Astana - $1 \%$, so they did not cause serious financial market risks, but for several years, banks which were able to provide banking services, could not avoid the risks that can not be predetermined. 


\section{ENTREPRENEURSHIP AND SUSTAINABILITY ISSUES}

ISSN 2345-0282 (online) http://jssidoi.org/jesi/

2020 Volume 7 Number 4 (June)

http://doi.org/10.9770/jesi.2020.7.4(46)

And as a result, we have nowadays this situation. In the crisis, the problems of banks can be solved only by the state, and can create all conditions for the restoration of financial relations and further development of the economy of the country as a whole (Lavrushina, Valentsova, 2016; Fakhry et al, 2018; Tvaronavičienė et al., 2018; Ashraf et al., 2019; Rahman et al., 2019; Siddique et al., 2020). Such government support is only applicable to a particularly serious systemic crisis.

\section{Materials and methods}

When considering the state of the loan portfolio of the second-tier banks of the Republic of Kazakhstan, JSC "Kazkommertsbank" failed to meet financial difficulties and could not resolve the internal risks in due course, this year it was transferred to JSC Halyk Bank. Halyk Bank JSC is currently holding the group. When analyzing the eight banking sectors in Kazakhstan, we see that second-tier banks can not lend money properly to the country's economy and lending is slowly growing.

Let's consider the loan portfolio of eight major banks in the financial market.

1. Loan portfolio of JSC Halyk Bank is $28 \%$.

2. In Tsesnabank JSC makes $19 \%$.

3. Sberbank JSC is $11 \%$.

4. Bank Center Credit makes up $11 \%$.

5. Kaspi Bank JSC makes up $9 \%$.

6. ATF Bank is $8 \%$.

7. The Eurasian Bank makes $8 \%$.

8. The Forte Bank has a stake of $9 \%$. (figure 1).

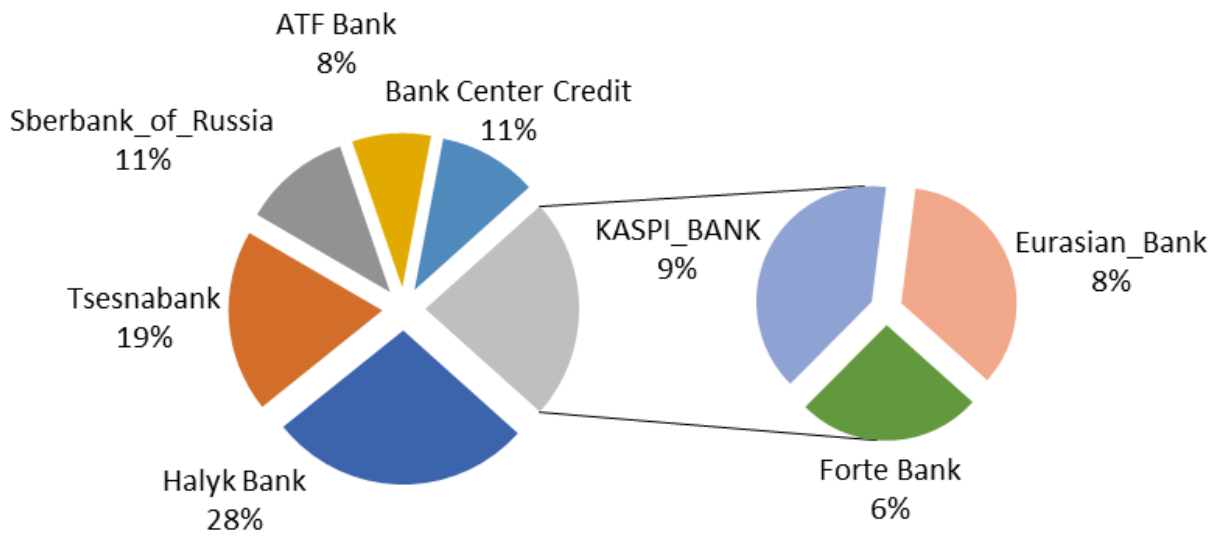

Figure 1. The percentage of loan portfolio of some second-tier banks of the Republic of Kazakhstan in 2017. Source: compiled by authors according to www.nationalbank.kz

When considering the share of the loan portfolio in the financial market, we can see that banks providing retail lending, that's to say, loans which pay special attention to consumers and serve individuals - Kaspi Bank JSC $9 \%$, Eurasian Bank - 8\%, Forte Bank - 9\%, they make $23 \%$ of the whole market.

Apart from the functional activity of the bank, it performs public functions and carries out monetary and credit policy. Due to market changes, the bank's operations are at greater risk.

Identification and control of the bank's risks are of interest to most parties. 
The estimation of the actual risk level for the bank consists of two approaches.

a) evaluation of risk level indicators.

b) classification of assets by risk groups.

Classification of risk indicators can be based on risk size and indicator type. Depending on the extent of risk associated with its object valuation, the bank's portfolio risk, personal risk and complex risk method are determined (International convergence of capital measurement and capital standards, 2018). The bank's asset quality affects all aspects of banking operations.

If the borrowers do not pay interest on the loan, the net profit of the bank will decline. In turn, low incomes (net income) can lead to lack of liquidity. In case of insufficient funds, the bank must increase its liabilities only to cover administrative expenses and interest on its current loans.

Unstable (low) net profit does not allow to increase bank capital (International convergence of capital measurement and capital standards, 2018). The quality of bad assets directly affects capital. If the borrowers do not pay the principal amount of the loan, the assets require the cost and the capital will be reduced, and the excessive debt is currently at the level of the credit risk. Let's consider the assets of eight major banks in the financial market (figure 2).

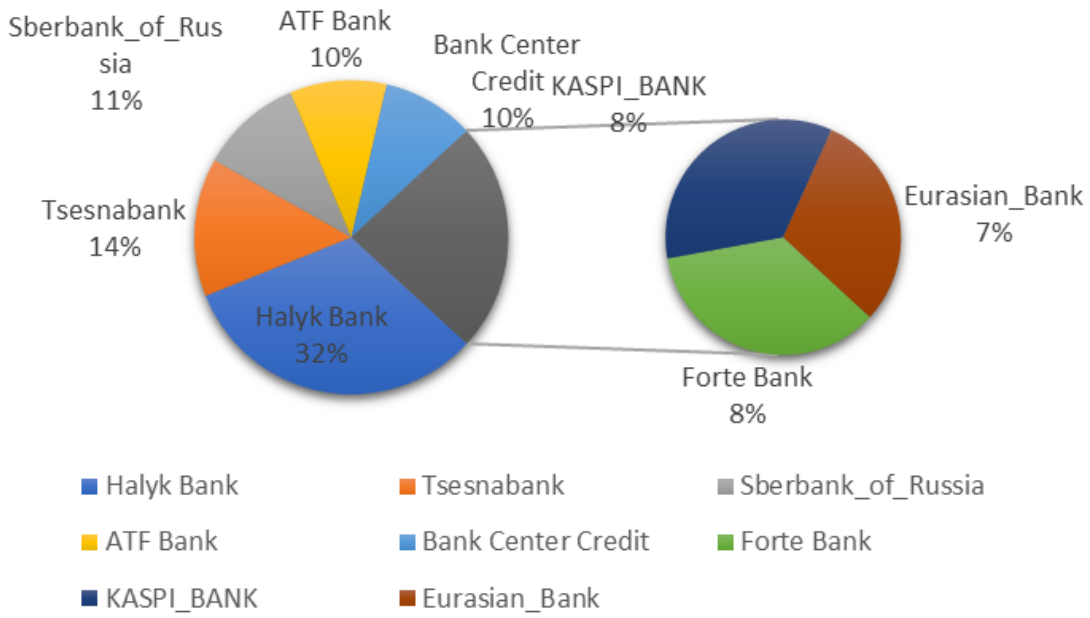

Figure 2. The percentage of assets of some second-tier banks of the Republic of Kazakhstan for 2017. Source: compiled by authors compiled by authors according to www.nationalbank.kz

Analysis of this diagram shows that Halyk Bank has 32\%, Tsesnabank 14\%, Sberbank JSC 11\%, Bank Center Credit 10\%, ATF Bank 10\%, Kaspi Bank 8\%, Forte Bank 8\%, Eurasian Bank $7 \%$ in total.

The statistical characteristics of the variables analyzed are shown in Table 1. Based on banks' performance indicators. The dependent variables were obtained from banks' assets. Obligations of the bank's assets have connections with ROA, NPL, ROE. We can verify the factors that are important by using the X1 through X14 GRETL. Model 1: Method of small squares (MSS) (Table 1). 
Table 1. Model 1: Gretl // MSS, obtained from indicators 1-32 $(\mathrm{n}=31)$

Dependent variable: Assets

\begin{tabular}{|l|c|c|c|c|c|}
\hline & Coefficient & Std. error & t-ratio & P value & \\
\hline Assets & 37,1610 & 7,69979 & 4,826 & 0,0002 & $* * *$ \\
\hline Liabilities & $-0,234111$ & 0,0973366 & $-2,405$ & 0,0295 & $* *$ \\
\hline Growth_of_capital & 0,139726 & 0,0978570 & 1,428 & 0,1738 & \\
\hline Loans_90d & $6,23238 \mathrm{e}-08$ & $4,24799-08$ & 1,467 & 0,1630 & \\
\hline Eqity & $2,36734 \mathrm{e}-08$ & $3,53929 \mathrm{e}-08$ & 0,6689 & 0,5137 & \\
\hline Size & 0,0128938 & 0,0872006 & 0,1479 & 0,8844 & \\
\hline ROA & 1,40032 & 0,593173 & 2,361 & 0,0322 & $* *$ \\
\hline Credit_portfolio & $-2,20859 \mathrm{e}-09$ & $5,37361 \mathrm{e}-09$ & $-0,4110$ & 0,6869 & \\
\hline Portfolio & 0,0653407 & 0,0572242 & 1,142 & 0,2714 & \\
\hline Loans & 0,11953 & 0,138105 & 0,8106 & 0,4302 & \\
\hline NPL & $-1,8232 \mathrm{e}-07$ & $8,52823 \mathrm{e}-08$ & $-2,138$ & 0,0494 & $* *$ \\
\hline NPL1 & 0,00272259 & 0,00810237 & 0,3360 & 0,7415 & \\
\hline Deposits & $-9,26334 \mathrm{e}-09$ & $7,14746 \mathrm{e}-09$ & $-1,296$ & 0,2146 & \\
\hline Deposits1 & 0,0241578 & 0,0358259 & 0,6743 & 0,5104 & \\
\hline ROE & $-0,396898$ & 0,153341 & $-2,588$ & 0,0206 & $* *$ \\
\hline CIR & $-0,0891888$ & 0,0473814 & $-1,882$ & 0,0793 & \\
\hline
\end{tabular}

\begin{tabular}{|l|r|l|l|r|}
\hline Mean dependent var & 16,80645 & & S.D. dependent var. & 9,371657 \\
\hline Sum squared resid & 275,0365 & & Standard error & 4,282028 \\
\hline R- squared & 0,895615 & & Adj. R-squared & 0,791231 \\
\hline F(7, 24) & 8,579961 & & P- value (F) & 0,000077 \\
\hline Logical likelihood & $-77,82230$ & & Akaike Criterion & 187,6446 \\
\hline Schwarz Criterion & 210,5884 & Hannan-Quinn Criterion & 195,1237 \\
\hline
\end{tabular}

In this model, the banks were ranked on the financial market, including Assets, Liabilities, Loans 90d (Doubtful Loans for Over 90 Days), Eqity (Capital), Credit portfolio, Loans, they were calculated by the Gretl model (The official website of the Committee on Statistics of the Ministry of National Economy of the Republic of Kazakhstan, 2018).

By analyzing, we assume that the predicted X4 is of importance in the equation model, since its P-value is greater than 0,05 , although its multicollinearity. That is, our model will appear in the equation $(\mathrm{y}=\mathrm{a} 0+\mathrm{a} 1 \mathrm{x} 1)$. In our case, the independent factor $\mathrm{X} 1$ is important because we see that its value is much smaller than $\mathrm{P}=0.05$, i.e. zero hypothesis is rejected and an alternative hypothesis is confirmed. Also, we can verify it by using t-ratio.

On the basis of the obtained data it may be written many regression equations. However, we can only be sure of the fact that our model is important:

a) to estimate the statistical significance of multiple regression equation coefficients using the Student Criterion. b) the quality of the regression model is assessed on the basis of the Fisher Criterion, which describes the statistical significance of the model and the feasibility of using it to analyze and predict the research object.

In the correlation-regression analysis, we have determined that assets can be a significant indicator for the liabilities and ROA, ROE, NPL variables. From Table 1 , we see that R-squared $=0.89$ and often R is not a correlation coefficient, but its multiplicity (common) factor R2 - squared. 


\section{ENTREPRENEURSHIP AND SUSTAINABILITY ISSUES}

ISSN 2345-0282 (online) http://jssidoi.org/jesi/

2020 Volume 7 Number 4 (June)

http://doi.org/10.9770/jesi.2020.7.4(46)

The coefficient P2 $=0.89$ is explained by factors included in the $89 \%$ model of effective fluctuation indicator, and $11 \%$ are explained by other factors not included in the model. The state is interested in helping the systemic banks, which play an important role in the economy of the country.

For example, bankruptcy of one or several strategically important banks in our country may be difficult for the country's economy, as the interests of ordinary depositors, businesses (enterprises, firms with accounts in banks) may suffer. Another important factor of state support for large banks is their long-term strategic interests in banking business development. In the study of risk it is necessary to distinguish two main directions (Rogachev, 2016).

- detection of risk level

- deciding on risk reduction.

The low level of corporate governance, including the risk management system in banks, and the low level of managerial bodies' responsibilities can be noted (Leontiev, Privalova, 2017). The state has taken a decision on state support for the economy on the basis of the systemic importance of large banks, on the banks' capitalization, through the active involvement of the bank's shareholders.

Due to the stagnation in the banking sector, the government continues to support this sector. In this regard, in relation to mid-sized banks, the National Bank has taken steps to eliminate the negative experience of nonperforming loans in relation to the loans and assets in the future.

Bank crises are worse than production crises, as they lead to many financial losses for participants linked through the cash flow chain. When choosing the bank's strategy, the banking services market and its segments are studied (Makysh, 2016). One of the most dangerous strategies is the strategy of the leader and strategy for the sale of new services in the new market (Konovalova, 2018).

Strategy for working with VIP-clients is also a matter of personalization of services. In the case of an adverse event, i.e. the occurrence of the risk not only in the bank, but also in the clients of the bank, or vice versa, if the problem arises in the client, it also affects the bank.

\section{Results and Discussion}

The financial situation of the banks mostly affects loans, which are more than 90 days, i.e. problematic doubtful loans. In the banking environment, it is NPL, which reflects the total amount of overdue and overdue debt in the loan portfolio. Several banks have been defaulted this year because of the sharp rise in NPL. Borrowers of the bank make it difficult to overcome their burden.

At the request of respondents, $43 \%$ face financial difficulties (twice a year). As for the NPLs of the banks of the Republic of Kazakhstan, the situation is lower, that is to say, there is NPL volume of eight banks in the market (figure 3). 


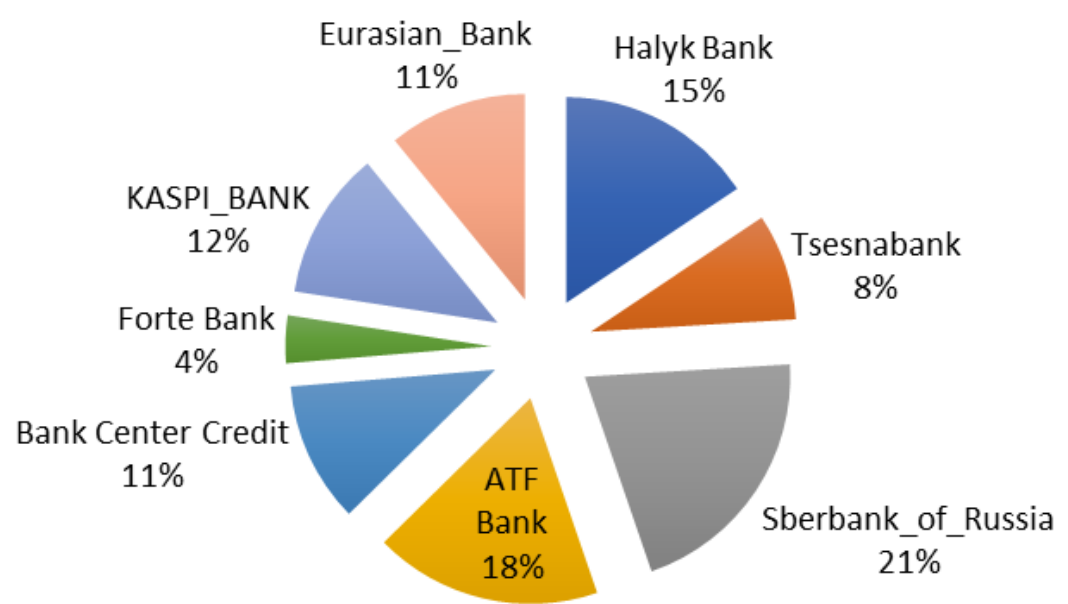

Figure 3. The percentage of NPL level of some second-tier banks of the Republic of Kazakhstan in 2017.

Source: compiled by authors according to www.nationalbank.kz

NPL is a non-performing loan, loans other than those whose principal loans are overdue for a period of 90 days or more, and other reasons for suspicion that loans and receivables can be fully credited, loans not covered by the original loan agreement requirement. Most overdue loans can bankrupt the bank.

If we build a model using $\mathrm{R}$ - programme, we get a box plot. A box plot, a span diagram is a graph used in descriptive statistics, compactly depicting a one-dimensional probability distribution. This type of diagram in a convenient form shows the median, the lower and upper quartiles, the minimum and maximum sampling values and outliers.

- Median * (50\% quartile) is a line in the middle of the rectangle

- Upper and lower quartiles (25\% and 75\%) - the upper and lower borders of the rectangle

- Observed minima and maxima

- As well as outliers in data, as individual points (figure 4). 

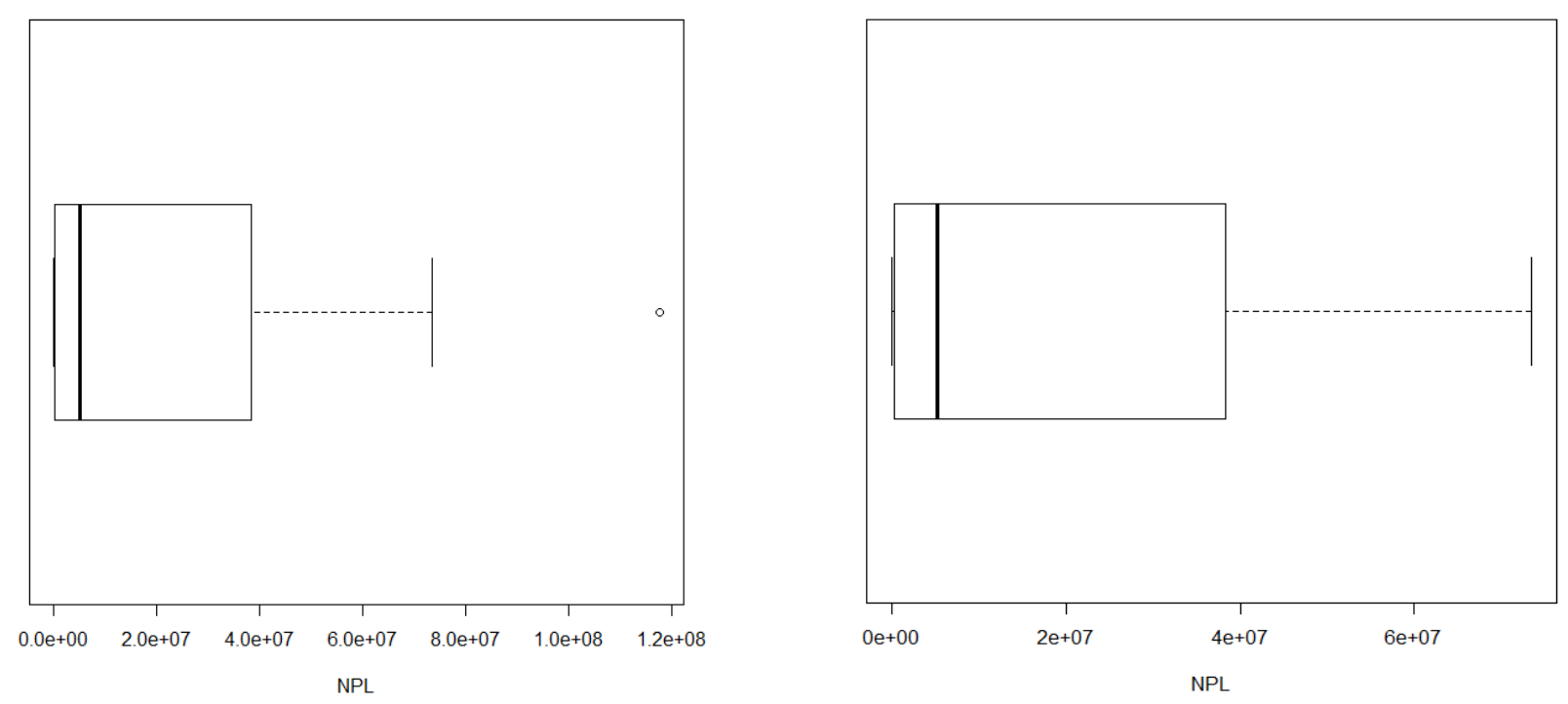

Figure 4. BOX PLOT of NPL to detect outliers Source: compiled by authors

Analyzing the "box plot" chart, we see that the Median shows * that 50\% of banks 'customers have overdue loans more than the amount of 5131245 Tenge, and the remaining 50\% of banks' customers have debts less than this amount.

If we focus on the range of overdue loans between the lower and upper quartiles, in which $50 \%$ of the studied data are concentrated, we can say that the lower quartile shows the value of NPL, below which a quarter (25\%) of the available data contains the total value of the urgent and overdue debt in the loan portfolio.

The upper quartile shows that $75 \%$ of clients in all the banks studied have a delay of 4.0 million Tenge.

The "box plot" diagram for the NPL parameter (overdue debt of bank customers) has left-sided asymmetry, that is, our sample does not have Normal distribution or Gauss-Laplace law. Therefore, outlier was formed, which we see in the figure as a point on the diagram.

Figure 5 shows some of Kazakhstan's second-tier banks with NPL, loan portfolio, loans over 90 days, asset level in percentage. 


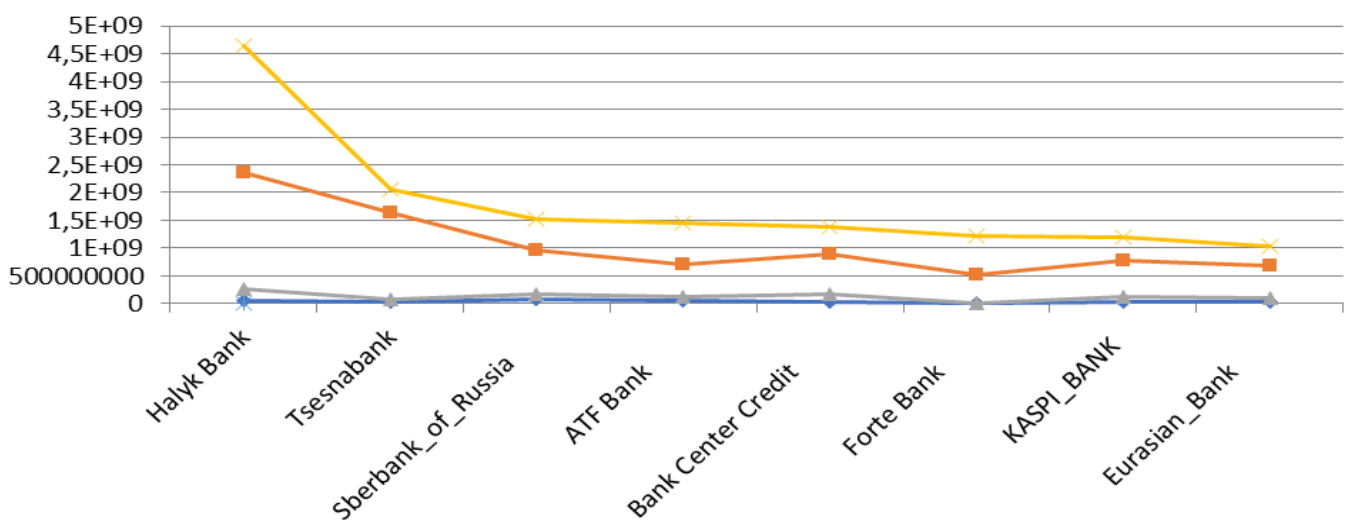

Figure 5. Kazakhstan's second-tier banks with NPL, loan portfolio, loans over 90 days, asset level in percentage. Source: compiled by authors

Following the results of the first nine months, the bank's loan repayment increased by $42 \%$ compared to the same period last year. Over the past few years, a record 30\% growth has been observed, and every fourth credit is a problematic issue. Using the GRETL application, we will issue the following report (table 2):

Table 2. Model 2: Gretl // MSS, obtained from index 1-32 $(\mathrm{n}=31)$ Dependent variable: NPL (non-performing loan)

\begin{tabular}{|l|c|c|c|c|l|}
\hline & Coefficient & Std. error & $t$-ratio & P value & \\
\hline Assets & -577721 & 254828 & $-2,2671$ & 0,0327 & $* *$ \\
\hline ROA & 109521 & $1,43442 \mathrm{e}+06$ & 0,0764 & 0,9398 & \\
\hline Liabilities & 265249 & 70619,1 & 3,7560 & 0,0010 & $* * *$ \\
\hline Equity & $-0,0786939$ & 0,036191 & $-2,1744$ & 0,0398 & $* *$ \\
\hline ROE & -164751 & 342988 & $-0,4803$ & 0,6353 & \\
\hline Credit_portfolio & 0,00296448 & 0,00993649 & 0,2983 & 0,7680 & \\
\hline Loans_90d & 0,292296 & 0,0640243 & 4,5654 & 0,0001 & $* * *$ \\
\hline
\end{tabular}

\begin{tabular}{|l|r|l|l|r|}
\hline Mean dependent var & 20355959 & & S.D. dependent var. & 29276781 \\
\hline Sum squared resid & $2,62 \mathrm{e}+15$ & & Standard error & 10452510 \\
\hline R- squared & 0,931998 & & Adj. R-squared & 0,914997 \\
\hline F(7, 24) & 46,98981 & & P- value (F) & $1,75 \mathrm{e}-12$ \\
\hline Logical likelihood & $-541,0531$ & & Akaike Criterion & 1096,106 \\
\hline Schwarz Criterion & 1106,144 & Hannan-Quinn Criterion & 1099,378 \\
\hline
\end{tabular}

This Gretl model has only a few dependent variables that have been excluded from the previously unrelated indexes. They include Assets, Liabilities, Loans_90d (doubtful loans more than 90 days), Equity, Credit portfolio (loan portfolio). Variable NPL - (non-performing loan). The variable NPL has a strong relationship between Liabilities, Assets, Equity and Loans_90d. F = 46.9, which is greater than the table F $=4.057$.

Consequently, our model is relevant and important and can be used for further forecasting. From Table 2 we see that $\mathrm{R}$ - squared $=0.91$ and often $\mathrm{R}$ is not the correlation coefficient, but its multiplicity (common) coefficient $\mathrm{R} 2$ squared. By Fisher Criterion. 


\section{ENTREPRENEURSHIP AND SUSTAINABILITY ISSUES}

ISSN 2345-0282 (online) http://jssidoi.org/jesi/

2020 Volume 7 Number 4 (June)

http://doi.org/10.9770/jesi.2020.7.4(46)

$\mathrm{P} 2=0.91$ is explained by the factors included in the model $91 \%$ of the effective indicator deviation, and $9 \%$ are explained by other factors not included in the model.

In the correlation-regression analysis, we have determined that assets, liabilities, doubtful loans over 90 days, will be significant indicators for NPL capital.In correlation-regression analysis, we have found that NPL is a significant indicator for other variables.

The current risk management is to monitor important indicators and to adopt operative decisions on the basis of banking operations. The mechanism of risk protection of banks consists of risk management current methods and its reduction (Kuzmicheva, Podkolzina, 2015).

The following elements are included in the risk supervisory system:

- methods of risk identification, methods of risk assessment, risk control mechanism.

The risk management policy is designed to ensure that the banking services market meets the efficiency and scope of the bank's operations (Pimenov, 2016).

The main objectives of the risk management policy are:

- formation principles of creation of high-quality assets portfolio;

- taking into account the risks of banking capital, their safety, formation of the asset portfolio, increasing the volumes of operations by maintaining an acceptable level of risk, developing the risk management system; modernization and creation of new approaches to risk management; development of risk management culture in the bank.

The role of consumer protection from the negative effects of the bankruptcy of the bank is related to the deposit insurance system in 140 countries, including Kazakhstan. Deposit guarantee is one of the types of security cushion and joint insurance against hedging of the savings of the population at the expense of the banking sector (Materials Basel Agreement, 2015). Moreover, in the last few years, despite the difficulties in the domestic financial market, the discoveries have egun to make positive changes. Kazakhstan has moved to the inflationoriented and free floating exchange rate, and there are many disagreements and misunderstandings in the society. Risk identification consists of hazard-defining routes (Lobanova, Chugunova, 2017).

The risk identification, along with identifying hazardous areas, also involves the bank's practical benefits and negative consequences of the potential associated with these areas. It is important to have good information base, which includes the elimination and processing of relevant information, to identify the risk and other elements of its management system. The role of the relevant information is crucial for any risk.

Qualitative and quantitative analysis is carried out to assess the degree of risk.

- Qualitative analysis is an analysis of risk areas and potential hazardous areas identified by factors. On this basis, qualitative analysis is based on a clear definition of the factors characterizing each type of bank risk. The model of qualitative analysis is evidenced by the bank loan portfolio analysis (Prictup, Senchukova, 2015).

- Numerical analysis is aimed at risk assessment.

In the quantitative analysis it is possible to distinguish several blocks of conditionality: the choice of criteria of risk degree evaluation; determining the level of certain types of risks acceptable to the bank; determining the specific degree of risk based on individual methods; risk assessment or risk reduction in the future.

As the indicators of risk assessment can be given: factors; predictable loss; indicators of segmentation of the bank's portfolio (assets portfolio, credit, deposit resources, investments, trade portfolios, etc.). 


\section{ENTREPRENEURSHIP AND SUSTAINABILITY ISSUES}

ISSN 2345-0282 (online) http://jssidoi.org/jesi/

2020 Volume 7 Number 4 (June)

http://doi.org/10.9770/jesi.2020.7.4(46)

Risk control is a decision that is aimed at systematic analysis of risk indicators by risk types and minimizing risks, retaining their level of profitability. The risk control process consists of: allocating responsibility for risk monitoring, identifying risk management methods (Belozerov, 2017).

Responsibility for monitoring is assigned to the bank's functional subdivisions, its specialized committees, internal control, auditing and analysis. The rule is defined by a set of methods aimed at protecting the bank's risks. Risk control includes measures to timely identify risk for its reduction or elimination (Tarasov, 2014).

There are three methods of risk management: internal audit, external audit, internal control. Internal audit is carried out by the internal structural division of the bank, which includes an independent assessment of the adequacy and effectiveness of the bank. Internal audit is in the interests of the bank and regulated by its internal documents. Internal audit institutions include auditors appointed by bank holders, audit commissions, internal auditors or group of internal auditors (Hasanova, 2016). Risk control and supervisory is carried out within the bank's internal control system. Except for external auditing, internal audit objectives are modified to meet the management requirements.

The main purpose of the external auditor is to determine the reliability of the financial statements of the bank and the compliance of the reporting procedure with the legislation of the Republic of Kazakhstan.

The auditor expresses an opinion on all material aspects of the financial statements. It should first assess how effectively the internal audit service operates. Internal control of the risk management system is carried out by the representative of the risk management body (Volkov, 2015). Internal control of the risk management system is an effective risk prevention tool and is an assessment and monitoring of the effectiveness of risk management policy (Manuilenko 2018).

Study of causes of harm, development of measures to optimize business processes, risk control of new products and risky operations to minimize risks are also of great importance.

Special attention should be paid to credit risk management, because its quality depends on its quality.

The key elements of good governance include: availability of well-developed credit policy, credit portfolio management, effective debt management, and, most importantly, qualified staff to work in this system. Banks are the main function of cash redistribution through lending to the economy, and provide loans under various government programs to support entrepreneurship (Zaytseva, 2016). 33\% of the total loan portfolio of the banking system constitutes problem loans. In particular, some banks have been lending non-performing loans, without credit risk analysis, and most of them have not been refunded.

The overall view of risk management is as follows:

- studying the possible consequences of the risk;

- development of measures to prevent or minimize the harm;

- the risk assessment is likely to be neutralized.

However, much has been done to stabilize the situation on the money market (Schnatterly, Clark, Howe, DeVaughn, 2017). Presently, the conjuncture of Kazakhstani money market remains moderate, making 3.5 trillion Tenge due to continued liquidity structural surplus.

In the short term, the market rates are at the bottom of the base rates, which periodically affects volatility in the currency market. Since the branch oversight was simultaneously liberal, the state had to provide liquidity to the 


\section{ENTREPRENEURSHIP AND SUSTAINABILITY ISSUES}

ISSN 2345-0282 (online) http://jssidoi.org/jesi/

2020 Volume 7 Number 4 (June)

http://doi.org/10.9770/jesi.2020.7.4(46)

banks several times. Therefore, after changing the supervisory functions of the National Bank, it was possible to prevent the consequences of the previous oversight.

But in fact, banks needed help - in April 2017 in favor of the National Bank's current management a regulated banking sector rehabilitation program launched - a large number of non-performing loans in the system and a solution to this problem. There was a rehabilitation program in total amount of 653 billion Tenge for ATF Bank, Eurasian Bank, Tsesnabank Bank, CenterCredit and Bank RBK. The shareholders carefully monitor the events in the financial sector, so pension asset management should be balanced.

It should be noted that the volume of investments of foreign issuers in financial instruments has increased from $6.5 \%$ to $22.5 \%$ over the past two years. For the portfolio diversification, it is necessary to invest a foreign currency in liquid financial instruments of foreign issuers (Santos, 2018).

At the same time, the share of such investments is $22.5 \%$, as the remaining pension assets are invested in other sectors. The more risk diversification is, the better. For the fund's investors this year, the profitability of the UAPF's pension assets portfolio was $7.75 \%$, the inflation rate was $3.3 \%$.

On the eve of the Congress of financiers, experts negatively assessed the situation in Kazakhstan's financial sector. This year there was a test of strength for the banking sector of Kazakhstan. In 2018, two banks were able to reach the distance. In addition, for example, Bank Home Credit is confident in the market. Although the share of "bad" loans in the bank is small, the financial institution has improved the selection process for borrowers this year. The Bank continues to effectively develop its business, which is evidence of our financial performance. Since the beginning of the year the bank's assets have grown by $20 \%$, loan portfolio - by $12.6 \%$.

The achievement of such results was ensured by the active work of sales channels, with the largest retailers in the country, as well as the introduction of new conceptual market products. For example, customers with good credit histories and regular earnings are able to borrow at low interest rates. The maximum credit limit of 60 months for loyal customers of the Bank is 2 million Tenge. SB Home Bank JSC (Kazakhstan) is part of the International Finance Group "Home Credit", based on a highly effective risk management model.

The Bank uses high-tech scoring models used to estimate the borrower's solvency (Taylor, Begley 2016). The borrower's creditworthiness assessment processes are constantly being improved, and the bank's operations are improving gradually. The Bank annually allocates considerable funds for the development and upgrading of the risk management system.

Typically, this model works best with a large data array. At present the bank has an active customer base of 29 million clients. Taking this into account, the scoring model believes that it will be paid in a short time. However, because of the introduction of a swift model based on artificial intelligence, the quality of the loan portfolio has tripled.

Nowadays, this topic is being actively discussed; certain initiatives are being taken for the use of digital signature (EDS). As an experiment, it is assumed that the project will enable banks to independently produce EDS. That is, when the client first visits a bank, it receives EDS immediately. In subsequent banking operations, the borrower can not communicate directly with the bank. The most important for the bank is the security of customers.

Bank terminals are equipped with biometrics. Biometrics takes fingerprints of bank's card users. This technology protects clients from fraudsters because fingerprints are not the same. In India, Home Credit Group offers a loan, identifying its customers by scanning the lattices. In India, the population census is also scanned (Saifuddin, Scheule). If the government of the Republic of Kazakhstan steps in this direction, fraudulent schemes will be 


\section{ENTREPRENEURSHIP AND SUSTAINABILITY ISSUES}

ISSN 2345-0282 (online) http://jssidoi.org/jesi/

2020 Volume 7 Number 4 (June)

http://doi.org/10.9770/jesi.2020.7.4(46)

eliminated, and online credit line fixing will be fast and safe. In the world, many banks have cut off their affiliates and become Internet companies. At present, banks are mainly get profit from deposits.

\section{Conclusions}

The banking sector of the country changes according to customer demand. The requirement of time is digitalization of all spheres of life. The bank's business is its main competitive advantage and the financial institution, which has not made any move to change, is displaced from the market.

From the beginning of 2018, the largest bank of Kazakhstan, JSC "Tsesnabank" announced the transfer of strategic tasks to the first issue. Analysis and the study of the state of the economy can not exist without statistic data. "Tsesnabank" JSC is also a participant of state programs to support the priority sectors of the world and the banking sector, to support small and medium-sized businesses, and to implement significant infrastructure and industrial projects in the country. The development of Kazakhstan's regions influences the overall welfare of our fellow countrymen. The main indicators of the bank's effective work are keeping the regulator's requirements and maintaining continuous success, and for 25 years, Tsesnabank has fulfilled its obligations to the National Bank, its customers and reserve partners.

The bank faces predictable deviations in the global economy and other risks. In the entire history of the bank, the majority of shareholders have never changed, and in the near future they intend to capitalize again. In accordance with the action plan on financial stability, the bank has plans to fulfill its obligations early ahead. These decisions show that each shareholder is ready to assume personal responsibility for customers and market risks and regulatory requirements.

Personal plans of the bank is a further development of digital platforms and Internet banking. The bank tries to create a convenient ecosystem for its clients - all services required for business management and development will be concentrated in one place and will be available $24 / 7$ to customers.

Five banks participating in the National Bank's additional capitalization program in the first half of the year did not show a sharp decline in lending and market share in assets. The bank's risk management system co-ordinates ways and means of working with the bank's employees, allowing for positive financial outcomes, predicting the occurrence of risk events and taking action to eliminate or minimize their negative consequences.

Based on the types of banking risks, this system can be divided into complex blocks associated with risk management, debt liquidity risk, interest rate, operating risk, loss of profits, and risks arising from credit facility business lines. In the classification of other risks, the individual risk management subdivision and the total risk management unit are separated into independent units (Teodora).

The first block includes the risk management of credit operations and other types of banking operations, and the second one - various banking portfolios - credit, trade, investment, attracted resources etc. In our eyes, the banking sector of the country changes according to the consumer demand.

Risk identification includes areas that identify threats. In introducing the new system, the National Bank will ensure the continuous functioning of the financial sector and timely respond to the most pressing problems. The identification of risk includes identifying the hazardous areas and the potential benefits of the bank and its practical consequences associated with these areas. Additionally, the new system will adapt to the ever-changing financial risks of emerging markets. It is important to possess good information base, which includes access and processing of relevant information, to identify the risk as well as other elements of its management system. The directions of improvement of the banking risk management mechanisms based on the disclosure of the content of 


\section{ENTREPRENEURSHIP AND SUSTAINABILITY ISSUES}

ISSN 2345-0282 (online) http://jssidoi.org/jesi/

2020 Volume 7 Number 4 (June)

http://doi.org/10.9770/jesi.2020.7.4(46)

the risk management system were presented in the study. Obviously, the research itself can not be analyzed without the use of modern models using statistical data. The article highlights the fact that banks focus on the major domestic risks in the financial market.

\section{References}

Ashraf, M., Masood, O., Tvaronavičienė, M., Aktan, B., Garškaitė-Milvydienė, K. Lace, N. 2019. Factors Affecting Development Patterns: Econometric Investigation Of Japan Equity Market, Economic Research-Ekonomska Istraživanja, 32(1), 440-453, https://doi.org/10.1080/1331677X.2018.1551147

Belozerov, S. 2017. Insurance and risk management. Problems and prospects. Saint-Petersburg: Prospect, 528p.

Caplinska, A., Tvaronavičienè, M. 2020. Towards sustainability of financial system via complex assessment of borrower's creditworthiness Journal of Security and Sustainability Issues, 9(4). http://doi.org/10.9770/jssi.2020.9.4(23)

Fakhry, B., Aktan, B., Masood, O., Tvaronavičienè, M., Celik, S. 2018. The Impact Of A Recent Natural Disaster On The Japanese Financial Markets: Empirical Evidenece. Journal of Competitiveness, 10(2), 56-71, ISSN 1804-171X (Print), ISSN 1804-1728 (On-line). https://doi.org/10.7441/joc.2018.02.04

Hasanova, M.M. 2016. The role of commercial banks in the modern economy and the prospects for its development. Moscow. 525p.

International convergence of capital measurement and capital standards. Basel Committee on Banking Supervision. Moscow: Bank for International Settlements. 2018.

Iskakov, U.M. 2016. Banking: Textbook. Almaty: Economics, 776p.

Konovalova, O.M. 2018. Method (standard) of assessing the effectiveness of banking risk management. Banking, 3(11), $12-20$.

Kuzmicheva, I.A., Podkolzina, E.A. 2015. Bank risk management system. Basic research, 2(25), 535-563.

Lavrushina, O.I., Valentsova, N.I. 2016. Banking risks: textbook. Moscow: KNORUS, 232p.

Leontiev, V.E., Privalova, S.G. 2017. To the question of the nature and classification of banking risks. Manager, 1(47), $26-35$.

Lisak, B.I. 2017. Integrated risk management in banks: a textbook. Almaty: Publishing House "Economics". 227p.

Lobanova, A.A., Chugunova, A.V. 2017. Encyclopedia of financial risk management. Moscow: Alpina Publisher. 225p.

Makysh, S.B. 2016. Bank Theory. Almaty. 228p.

Manuilenko, V. 2018. In the implementation of the concept of return on capital, taking into account risk.Moscow. 556p.

Materials Basel Agreement. 2005. Business and banks.

Nazarbayev, N. 2018. Strategy: Growth of welfare of Kazakhstan by improving quality of life and income. Almaty. 338p.

Pimenov, N.A. 2016. Financial risk management. Moscow: Yurayt, 416p.

Prictup, N.P., Senchukova, A.S. 2015. Theoretical aspects of bank credit risk management. Modern scientific research and innovation, 6 (13), 25-32.

Rahman, A., Tvaronavičienè, M., Smrčka, L., Androniceanu, A. 2019. The Effect of Bank Competition on Cost of Credit: Empirical Evidence from the Visegrad Countries. Acta Polytechnica Hungarica, 16(4), 175-195. 


\section{ENTREPRENEURSHIP AND SUSTAINABILITY ISSUES}

ISSN 2345-0282 (online) http://jssidoi.org/jesi/

2020 Volume 7 Number 4 (June)

http://doi.org/10.9770/jesi.2020.7.4(46)

Rogachev, A.Yu. 2016. The modern role of commercial and regional banks. Economics and economic sciences, 4(13), 21-28.

Santos, A.C. 2018. Sovereign Capacity during a Financial Crisis: A Cross-Country Analysis. Jornal of Credit Risk, 5(11), 65-72.

Schnatterly, K., Clark, B. B., Howe, J., DeVaughn, M. 2017. Regulatory and govermance impacts on bank risk-taking. Romania, JARLE, 2 (17), 32-49.

Siddique, A., Masood, O., Javaria, K., Huy, D.T.N. 2020. A comparative study of performance of commercial banks in ASIAN developing and developed countries. Insights into Regional Development, 2(2), 580-591. https://doi.org/10.9770/IRD.2020.2.2(6)

Tarasov, A. 2014. Methods for estimating risk and return on investment parameters. Moscow: Ekonom, 109p.

Taylor, A., Begley, R. 2016. The Strategic Underreporting of Bank Risk.Moscow. 556p.

The official website of the Committee on Statistics of the Ministry of National Economy of the Republic of Kazakhstan. www.stat.gov.kz.

Tvaronavičienè, M., Masood, O., Javaria, K. 2018. Preconditions of the Eurozone economic security: how to overcome liquidity risk and cost inefficiency in leading banks of UK and Germany, Polish Journal of Management Studies, 18(1)418-427; https://doi.org/10.17512/pjms.2018.18.1.31

Volkov, A.A. 2015. Risk management in a commercial bank. Moscow: Omega. 125p.

Web-site of the National Bank of Kazakhstan. www.nationalbank.kz

Zaytseva, A.V. 2016. Insuraance of bank risk legal construction. main directions and importance in banking activities. Banking Low, 5 (11), 62-65.

Karlygash KAZBEKOVA is PhD student in Finance of the Narxoz University, Almaty, Kazakhstan. Research interests: banks, other credit institutions, economics and finance.

ORCID ID: orcid.org/0000-0001-8571-2311

Ainagul ADAMBEKOVA is Doctor of Economic Sciences, Professor of Narxoz University, Almaty, Kazakhstan. Research interests: banks, real estate mortgage loans, economics and finance.

ORCID ID: orcid.org/0000-0003-2026-4321

Sariya BAIMUKHANOVA is an Associate professor of the Kazakh National University named by al-Farabi, Almaty, Kazakhstan. Research interests: banks, other credit institutions, economics and finance.

ORCID ID: orcid.org/0000-0002-9128-4891 
Gulzhihan KENGES is a Candidate of Economic Sciences of the S.Seifullin Kazakh AgroTechnical University, Nur-Sultan, Kazakhstan. Research interests: management, banks, real estate mortgage loans, economics and finance.

ORCID ID: orcid.org/0000-0001-8529-8923

Daurenbek BOKHAEV is a Candidate of Economic Sciences of the Narxoz University, Almaty, Kazakhstan.Research interests: economics and finance, banks, real estate mortgage loans.

ORCID ID: orcid.org/0000-0002-0253-7026 